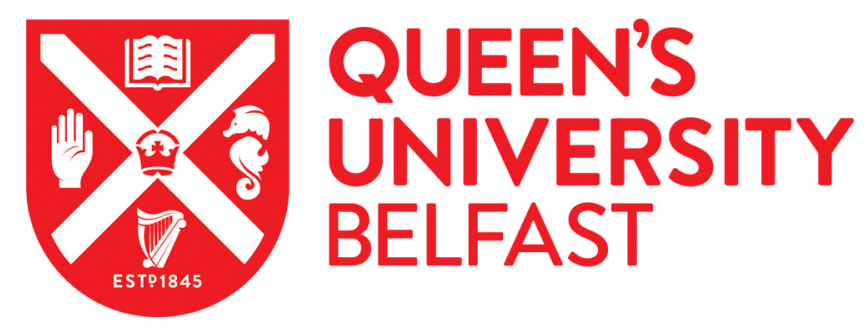

\title{
Next generation planar waveguide detection of microcystins in freshwater and cyanobacterial extracts, utilising a novel lysis method for portable sample preparation and analysis
}

Devlin, S., Meneely, J. P., Greer, B., Greef, C., Lochhead, M. J., \& Elliott, C. T. (2013). Next generation planar waveguide detection of microcystins in freshwater and cyanobacterial extracts, utilising a novel lysis method for portable sample preparation and analysis. Analytica Chimica Acta, 769, 108-113.

https://doi.org/10.1016/j.aca.2013.01.033

Published in:

Analytica Chimica Acta

Document Version:

Peer reviewed version

Queen's University Belfast - Research Portal:

Link to publication record in Queen's University Belfast Research Portal

\begin{abstract}
Publisher rights
this is the author's version of a work that was accepted for publication in Analytica Chimica Acta. Changes resulting from the publishing process, such as peer review, editing, corrections, structural formatting, and other quality control mechanisms may not be reflected in this document. Changes may have been made to this work since it was submitted for publication. A definitive version was subsequently published in Analytica Chimica Acta, [VOL 769, (2013)]
\end{abstract}

\section{General rights}

Copyright for the publications made accessible via the Queen's University Belfast Research Portal is retained by the author(s) and / or other copyright owners and it is a condition of accessing these publications that users recognise and abide by the legal requirements associated with these rights.

Take down policy

The Research Portal is Queen's institutional repository that provides access to Queen's research output. Every effort has been made to ensure that content in the Research Portal does not infringe any person's rights, or applicable UK laws. If you discover content in the Research Portal that you believe breaches copyright or violates any law, please contact openaccess@qub.ac.uk. 


\section{Accepted Manuscript}

Title: Next generation planar waveguide detection of microcystins in freshwater and cyanobacterial extracts, utilising a novel lysis method for portable sample preparation and analysis

Authors: Shauna Devlin, Julie P. Meneely, Brett Greer,

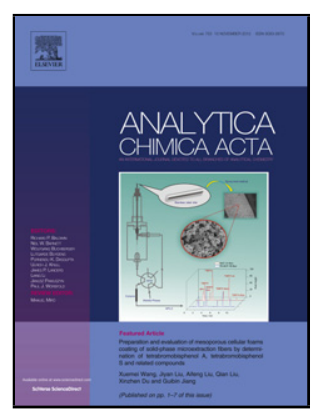

Charles Greef, Michael J. Lochhead, Christopher T. Elliott

PII:

S0003-2670(13)00181-5

DOI: doi:10.1016/j.aca.2013.01.033

Reference: ACA 232353

To appear in: $\quad$ Analytica Chimica Acta

Received date: $\quad 24-8-2012$

Revised date: $\quad 3-12-2012$

Accepted date: $\quad 14-1-2013$

Please cite this article as: S. Devlin, J.P. Meneely, B. Greer, C. Greef, M.J. Lochhead, C.T. Elliott, Next generation planar waveguide detection of microcystins in freshwater and cyanobacterial extracts, utilising a novel lysis method for portable sample preparation and analysis, Analytica Chimica Acta (2010), doi:10.1016/j.aca.2013.01.033

This is a PDF file of an unedited manuscript that has been accepted for publication. As a service to our customers we are providing this early version of the manuscript. The manuscript will undergo copyediting, typesetting, and review of the resulting proof before it is published in its final form. Please note that during the production process errors may be discovered which could affect the content, and all legal disclaimers that apply to the journal pertain. 
1 Next generation planar waveguide detection of

2 microcystins in freshwater and cyanobacterial

3 extracts, utilising a novel lysis method for portable

4 sample preparation and analysis

5

6 Shauna Devlin ${ }^{\mathrm{a}^{*}}$, Julie P Meneely ${ }^{\mathrm{a}}$, Brett Greer ${ }^{\mathrm{a}}$, Charles Greef ${ }^{\mathrm{b}}$,

7 Michael J Lochhead $^{\mathrm{b}}$ and Christopher T Elliott ${ }^{\mathrm{a}}$

$8{ }^{a}$ Institute of Agri-Food and Land Use (IAFLU), School of Biological Sciences, Queen's

9 University, Malone Road, Belfast, BT9 5BN, Northern Ireland

$10 \quad{ }^{b}$ MBio Diagnostics Inc, Boulder, Colorado, 80301, USA

11

$12{ }^{*}$ Corresponding author: Institute of Agri-food and Land Use, School of Biological

13 Sciences, Queen's University, Malone Road, Belfast BT9 5BN, Northern Ireland

14 Tel: $+44(0) 2890974279$

15 Fax: +44 (0) 2890976513

16 Email: sdevlin08@qub.ac.uk

17

18 
19 Highlights

20 Sensitive assay for the detection of the most common and toxic microcystin variants

21 Detection of free and cell bound microcystin for a true reflection of toxin content

22 Novel, highly effective lysis method enabling fast and portable disruption of cells

23 Validated to measure microcystins below 1 and $0.1 \mathrm{ng} \mathrm{ml}^{-1}$; free and intracellular

24 Next generation planar waveguide biosensor combining quantification and ease of use

\section{Abstract}

28 The study details the development of a fully validated, rapid and portable sensor based

29 method for the on-site analysis of microcystins in freshwater samples. The process

30 employs a novel lysis method for the mechanical lysis of cyanobacterial cells, with

31 glass beads and a handheld frother in only $10 \mathrm{~min}$. The assay utilises an innovative

32 planar waveguide device that, via an evanescent wave excites fluorescent probes, for

33 amplification of signal in a competitive immunoassay, using an anti-microcystin

34 monoclonal with cross-reactivity against the most common, and toxic variants.

35 Validation of the assay showed the Limit of Detection (LOD) to be $0.78 \mathrm{ng} \mathrm{ml}^{-1}$ and the

$36 \mathrm{CC} \beta$ to be $1 \mathrm{ng} \mathrm{ml}^{-1}$. Robustness of the assay was demonstrated by intra- and inter-

37 assay testing. Intra-assay analysis had \% C.V.s between 8 and $26 \%$ and recoveries

38 between 73 and $101 \%$, with inter-assay analysis demonstrating \% C.V.s between 5 and

$3914 \%$ and recoveries between 78 and 91\%. Comparison with LC-MS/MS showed a high

40 correlation $\left(\mathrm{R}^{2}=0.9954\right)$ between the calculated concentrations of 5 different

41 Microcystis aeruginosa cultures for total microcystin content. Total microcystin

42 content was ascertained by the individual measurement of free and cell-bound

43 microcystins. Free microcystins can be measured to $1 \mathrm{ng} \mathrm{ml}^{-1}$, and with a 10 -fold

44 concentration step in the intracellular microcystin protocol (which brings the sample

45 within the range of the calibration curve), intracellular pools may be determined to 0.1 
$46 \mathrm{ng} \mathrm{ml}^{-1}$. This allows the determination of microcystins at and below the World Health

47 Organisation (WHO) guideline value of $1 \mu \mathrm{g} \mathrm{l}^{-1}$. This sensor represents a major

48 advancement in portable analysis capabilities and has the potential for numerous other

49 applications.

50

51 Keywords: Microcystin, planar waveguide, portable biosensor, novel lysis, blue-green

52 algae and cyanobacteria

\section{1. Introduction}

56 Cyanobacteria (Domain Bacteria) originate from the Precambrian era, 3.4 billion years

57 ago and were the first prokaryotes to use water in the fixation of carbon dioxide [1].

58 They are widespread throughout global waters, both marine and freshwater,

59 encompassing, not only hot tropical to temperate waters, but even the chilly waters of

60 the Antarctic ice shelves [2]. Of the many types of cyanobacteria, Microcystis

61 aeruginosa (predominantly freshwater) is the most common species, which produces

62 microcystins. In addition to Microcystis, microcystins are also produced by the

63 following genera: Anabaena, Nostoc, Planktothrix, Anabaenopsis and

64 Hapalosiphon [2]. Microcystins are cyclic heptapeptides with the structure; cyclo-(D-

65 Alanine-X-D-MeAsp-Y-Adda-D-Glutamate-Mdha), where X and Y are variable L-

66 amino acids, MeAsp and Mdha are Methylaspartic acid and Methyldehydroalanine,

67 respectively and Adda is (2S, 3S, 8S, 9S)-3-amino-9-methoxy-2,6,8-thrimethyl-10-

68 phenyldeca-4(E),6(E)-dienoic acid [3]. There are over 90 variants of microcystins with

69 the most common being Microcystin-LR (MC-LR), which has Leucine at position 2 
70 and Arginine at position $4[4,3]$. They are hepatotoxic, due to their uptake via the bile

71 acid transport system delivering them into hepatocytes, where they inhibit

72 Serine/Threonine Proteases via Adda, causing over phosphorylation of proteins. Acute

73 toxicosis results in the disruption of the cytoskeleton, loss of cell structure and

74 adhesion, loss of tissue structure and the collapse of sinusoidal capillaries resulting in

75 hepatic haemorrhaging and ultimately death [5-8]. The deaths of 60 patients in a

76 dialysis unit in Brazil, in 1996, have been attributed to the use of contaminated water

77 during dialysis [9]. Lower levels of microcystins, although not acutely lethal, have

78 been shown to promote cancer (Group 2B carcinogen; possibly carcinogenic to

79 humans) and have immunotoxic and genotoxic effects [10-12]. The World Health

80 Organisation (WHO) have set the recommended limit at $1 \mu \mathrm{g} \mathrm{l^{-1 }}$ for drinking water and

$8120 \mu \mathrm{g} \mathrm{l}^{-1}$ for recreational waters [13-15]. Microcystins are small (MC-LR being 995.2

$82 \mathrm{Da}$ ) and stable compounds, withstanding harsh conditions, such as high temperatures

83 and extreme $\mathrm{pH}$. Removal is usually achieved by activated carbon filtration, ozonation

84 or chlorination; all being commonly utilised in water treatment [16-18].

86 The ability to detect microcystins is important and many tests exist. The vast majority

87 are laboratory based, with immunoassays enabling high throughput screening for total

88 microcystin concentrations and analytical methods (such as HPLC, Mass

89 Spectrometry[19-21]), although slower, allowing the quantification and identification

90 of individual variants within a sample $[22,3]$. Recent attention has turned towards the

91 on-site detection of microcystins. Portable tests have long since focused on the lateral

92 flow format, a major drawback of which is that quantification usually relies on the

93 user's determination. However, the first lateral flow device (LFD) for microcystins,

94 devised by Kim et al (2003) [23], employed a custom made portable-laser fluorescence 
95 scanner, eliminating the subjective nature of results interpretation. For this they used

96 Alexa Fluor $647 \AA$, a Cy5 labelled fluorescent probe, as the secondary, detection,

97 antibody, in a competitive assay, whereby a MC-LR conjugate was coated to the

98 surface and an anti-MC-LR monoclonal was used as the primary antibody. This assay

99 format works well for most biosensors, including planar waveguide, a technology, that

100 has been around for decades. Two portable assays, have been developed recently by

101 Long et al (2005) and Herranz et al (2012) [24, 25]. Both utilise modified versions of

102 the aforementioned assay format; Long et al use a Cy5 labelled monoclonal, and

103 Herranz coat the sensor surface with MC-LR as opposed to a MC-LR-conjugate. The

104 biosensors used are the Trace Organic Pollutant Analyser (TOPA) and a

105 commercialised version of the US Naval Research Laboratory (NRL) Array Biosensor

106 prototype, by Long et al and Herranz et al respectively. For the TOPA assay, one

107 analyte was measured at a time, with a cycle time of $20 \mathrm{~min}, 150$ cycles per surface and

108 an LOD of $30 \mathrm{ng}^{-1}$. The NRL Biosensor, can detect up to 6 analytes at a time, with

10915 cycles per surface, a cycle time of $60 \mathrm{~min}$ and an LOD of $16 \mathrm{ng} \mathrm{l}^{-1}$. The present

110 study utilises the next generation of evanescent wave/ planar waveguide detection. This

111 platform has all the advantages related to single use LFDs and portable biosensors yet

112 has the ability to perform the accurate quantification only associated with laboratory

113 based, methods. The unique MBio SnapEsi ${ }^{\circledR}$ LS sensor [26] employed in the present

114 study uses, a patented design, whereby the lens is integrated on a disposable cartridge; a

115 cartridge into which the sample and reagents are added and held. The cartridges are

116 custom made, spotted with (in-house prepared) toxin-protein conjugates, chosen and

117 optimised for the sensitive and selective binding of anti-microcystin monoclonal

118 antibody (also produced in-house). These cartridges eliminate the need for

119 cumbersome and expensive microfluidics often associated with advanced portable 
120 sensors, thus there is no need for pumps, valves, tubing or buffer/waste reservoirs. In

121 the SnapEsi ${ }^{\circledR}$ LS assay there are no concerns about tubing becoming blocked; either by

122 lines drying out due to warm temperatures, air bubbles, or sample particulate blockages.

123 The cartridge can simply be used, read and disposed of. Thus a simple to use, low cost

124 and accurate means of detecting microcystins will be presented.

125

126 Further to this, we present a highly novel sample preparation method for the portable

127 lysis of cyanobacterial, Microcystis aeruginosa, cells, for the quantification of intra-

128 cellular microcystin levels. Microcystins are inherently endotoxins, therefore, the

129 measurement of freshwater only, fails to detect the majority of toxin present, as has

130 been highlighted by Codd et al (2005) [2] who state that guideline values "should

131 therefore apply to the sum of the intracellular and extracellular microcystin pools"; yet

132 the focus has remained on water testing only. This may be in part due to the difficulties

133 encountered in dealing with cyanobacterial samples in current analytical methods.

134 Cheap, quick and portable lysis usually relies on chemical disruption of cells, using

135 harsh reagents which may interfere with downstream assays, causing matrix

136 interference and thus skewing results. The best cellular disruption occurs via

137 mechanical lysis of the cells, such as that of glass bead beating, which has been

138 demonstrated to achieve full lysis of algal cells, in a quick time of only $10 \mathrm{~min}$ [27].

139 This laboratory based method required a paint shaker to mix the sample/glass bead

140 combination and a centrifuge to separate cells from freshwater samples. To overcome

141 this, centrifugation steps were switched to filtration and the paint shaker was substituted

142 for a, low cost, hand-held, battery operated frother. Other non mechanical methods

143 require filtration of the sample (glass fibre filters, GF/C) followed by slow toxin

144 extraction using solvents which are not compatible with immunoassays. 
146 Presented here is an assay, proven to be capable of detecting microcystins in both free

147 and intracellular states, to a level of $1 \mathrm{ng} \mathrm{ml}^{-1}$ for free and $0.1 \mathrm{ng} \mathrm{ml}^{-1}$ for intracellular 148 microcystins. This rapid, semi-quantitative test, has an assay time of only 15 min for 149 free microcystins, and under $30 \mathrm{~min}$ for intracellular microcystins, inclusive of sample 150 preparation.

\section{Materials and Methods}

\subsection{Reagents and Chemicals}

158 Microcystin-LR was purchased from Enzo Life Sciences, through Alpha Technologies

159 Ltd, Larne Northern Ireland. Bovine Serum Albumin (BSA), Phosphate buffered saline 160 (PBS) tablets, Tween-20 and apo-Transferrin (bovine) were purchased from Sigma161 Aldrich, Gillingham, UK. Cyanobacterial cultures were obtained from the Culture 162 Collection of Algae and Protozoa (CCAP), Oban, Scotland and the Laboratory of 163 Ecotoxicology, Genomics and Evolution (LEGE) at the Centre of Marine and 164 Environmental Research (CIIMAR), Porto, Portugal. From CCAP M. aeruginosa strains $1651450 / 3$ (non-toxic) and 1450/6 (toxic) were purchased and from CIIMAR, strains 166 LEGE 91093, LEGE 91094, LEGE 91095 and LEGE 91096 were received. Jaworski's 167 and BG11 media were purchased from CCAP, Oban, Scotland. Alexa Fluor 647 goat 168 anti-rabbit IgG and Alexa Fluor 647 goat anti-mouse IgG antibodies were purchased 
169 from Invitrogen Ltd, Paisley, Scotland. The anti-microcystin, 5C4, monoclonal was

170 prepared in-house and details will be published elsewhere.

\subsection{Apparatus}

173 For cell lysis a hand held frother was purchased from Argos Direct, Stafford, UK, while

174 the paint shaker, a Minimix standard shaker, was purchased from Merris Engineering,

175 Berkshire, UK. Swinnex, $25 \mathrm{~mm}$ filter holders, 25mm gaskets and $25 \mathrm{~mm}$ MF-

176 Millipore (mixed cellulose esters, hydrophilic, $0.45 \mu \mathrm{m}$ and black gridded) membranes, 177 together with Millex-HA $(0.45 \mu \mathrm{m}$, mixed cellulose) filters were purchased through 178 Premier Scientific Ltd, Belfast, Northern Ireland. The SnapEsi ${ }^{\circledR}$ LS System [28] was 179 supplied by MBio Diagnostics Inc, Boulder, Colorado, USA, as were the microarray 180 cartridges. MC-LR-Transferrin

184 MC-LR, $0.25 \mathrm{mg}$, was reconstituted in $50 \mu \mathrm{l}$ Dimethyl sulfoxide (DMSO). To this was

185 added $50 \quad \mu l \quad N$-Hydroxysuccinimide (NHS) $(130 \quad \mathrm{mM})$ and $100 \quad \mu l \quad \mathrm{~N}-(3-$

186 Dimethylaminopropyl)-N'-ethylcarbodiimide hydrochloride (EDC) (39 mM), both 187 dissolved in $50 \mathrm{mM}$ 2-(N-Morpholino) ethanesulfonic acid (MES), pH 4.7. This was 188 stirred for $30 \mathrm{~min}$, protected from light, at room temperature. The active ester solution 189 was then added, dropwise to a vial containing $1 \mathrm{mg}$ of Transferrin dissolved in $1 \mathrm{ml}$

190 PBS $\mathrm{pH}$ 7.4. This was stirred at room temperature, for 2 hours, again protected from 191 light. The TPC was dialysed against PBS pH 7.4 and tested by ELISA. The TPC was 192 sent to mBio Diagnostics for microarray printing, at $100 \mu \mathrm{g} \mathrm{ml}^{-1}$. 


\subsection{Microarray Printing}

195 Microarrays were printed using a Bio-Dot AD3200 robotic arrayer. Briefly, spots were 196 produced, with a diameter of $0.5 \mathrm{~mm}$, using a Bio-Jet print head that dispensed $20 \mathrm{nl}$.

197 Four replicates of the TPC were printed onto a grid with $1 \mathrm{~mm}$ centres. Microarrays 198 were then blocked with a protein-based blocking agent $(0.5 \%$ casein in PBS with

199 Proclin300 antimicrobial) prior to spin-drying. Microarrays were then assembled into 200 an injection moulded cartridge, which contained a $5 \mathrm{~mm}$ wide fluidic channel (max 201 volume $30 \mu \mathrm{l}$ ) with a single inlet port for the addition of sample and reagents. Assays 202 were carried out on a rack, angled for optimum flow rate, enhancing passive fluid flow, 203 which is aided by capillarity due to the narrow fluidic channel.

\subsection{Culturing}

206 CCAP cultures were maintained in Jaworski's Medium, while CIIMAR LEGE cultures 207 were maintained in BG11 Medium. Culturing was done in glass Erlenmeyer flasks 208 (wide necked) with cotton wool plugs and foil lids and incubated at $20{ }^{\circ} \mathrm{C}$ with a light 209 intensity of $116 \mu \mathrm{mol} \mathrm{m} \mathrm{s}^{-1}$. All consumables were sterilised by autoclaving at $121{ }^{\circ} \mathrm{C}$

210 for 15 min. Culturing work was carried out in a pre-sterilised (via 30 min UV 211 exposure) UV3 HEPA PCR cabinet. Cultures were maintained in log phase, with fresh 212 cultures being seeded from denser cultures (nearing stationary phase); $40 \mathrm{ml}$ dense 213 culture added to $160 \mathrm{ml}$ fresh media. Culture growth was monitored by cell counting 214 using Lugol's stain and a haemocytometer under x200 magnification. 


\subsection{Sample Lysis}

217 A $25 \mathrm{~mm}$ swinnex filter (in a $25 \mathrm{~mm}$ Swinnex Filter Holder) was used to filter $50 \mathrm{ml}$ of 218 sample/culture. The filter membrane was then transferred to a $7 \mathrm{ml}$ bijou and the 219 captured cells resuspended with $5 \mathrm{ml} \mathrm{PBS} \mathrm{pH} \mathrm{7.4.} \mathrm{To} 5 \mathrm{ml}$ of sample/culture, $1 \mathrm{~g}$ of $220 \quad 0.1 \mathrm{~mm}$ glass beads was added to a small glass beaker $(15 \mathrm{ml})$, whose diameter was just 221 large enough to accommodate the frother whisk, whilst limiting the space for 222 beads/cells to accumulate in. The frother was then switched on and allowed to 'whisk' 223 the sample/bead mixture for $10 \mathrm{~min}$. Once finished the sample was twice filtered $(0.45$ $224 \mu \mathrm{m}$ Millipore), to ensure complete removal of glass beads/fragments; once should be 225 enough, but a second filtration was included in case the first filter was perforated. A 226 negative toxin producer (CCAP 1450/3) was treated in the same way to produce the 227 matrix in which calibrants are prepared.

\subsection{Assay}

\section{Reagent/ Sample Preparation}

\section{Assay Buffer}

232 The buffer was PBS pH 7.4 containing $0.05 \%$ Tween-20, $0.45 \mu \mathrm{m}$ filtered.

\section{Antibody Solutions}

235 The monoclonal antibody, 5C4 was diluted (v/v), 1 in 100, from the stock solution of 236 approximately $0.88 \mathrm{mg} \mathrm{ml}^{-1}$. The diluent was Assay Buffer containing 1\% BSA, the 237 BSA acting as a stabiliser. The working stock was maintained at $4{ }^{\circ} \mathrm{C}$ and diluted 238 again, with Assay Buffer (without the added BSA) to a final concentration of 1 in 23910000 , for use in the assay. The $5 \mathrm{C} 4$ monoclonal antibody was shown to have cross- 
240 reactivity for the most common microcystin variants, as follows: MC-RR, 108\%; MC-

241 YR, 68\%; MC-LA, 69\%; MC-LW, 71\%; MC-LF, 68\%; and Nodularin, 94\%.

242

243 The detection antibody, Alexa Fluor 647 goat anti-mouse IgG, was used to prepare a

244 detection antibody working stock solution, also stored at $4{ }^{\circ} \mathrm{C}$ (without added BSA),

245 protected from light. The stock solution was prepared by adding $100 \mu \mathrm{l}$ of each

246 antibody to $2 \mathrm{ml}$ of Assay Buffer. For use in assay conditions, a further 1 in 10 dilution

247 (with Assay Buffer) was required to get to the final $10 \mu \mathrm{g} \mathrm{ml}^{-1}$ working solution.

249 Calibrants

250 Calibrants were prepared from a $1 \mu \mathrm{g} \mathrm{ml}^{-1}$ solution of MC-LR, to yield concentrations 251 of $200,50,20$ and $0 \mathrm{ng} \mathrm{ml}^{-1}$, with dilutions made using Assay Buffer. These were then 252 used to spike $950 \mu \mathrm{l}$ of matrix, using $50 \mu \mathrm{l}$ per spike, to get final solutions with the 253 following concentrations: 10,2.5, 1 and $0 \mathrm{ng} \mathrm{ml}^{-1}$.

\section{Assay Conditions}

256 Equal volumes of 5C4 antibody and sample/calibrant were mixed and $150 \mu 1$ 257 immediately applied to the cartridge. After $7 \frac{1}{2} \mathrm{~min}, 150 \mu \mathrm{l}$ of detection antibody was 258 added. After $7 \frac{1}{2} \min (15 \mathrm{~min}$ total time) the cartridge was read using the SnapEsi 259 reader. 


\subsection{Liquid Chromatography Tandem- Mass Spectrometry} (LC-MS/ MS) Validation

263 Freeze-drying and solid phase extraction (SPE) were used to prepare and extract 264 microcystins from Microcystis aeruginosa samples for LC-MS/MS detection, as 265 reported elsewhere; using modified methods from Kim et al. (2009), Lawton et al. 266 (1994), Msagati et al. (2006) and Mooney et al. (2011) [29-31, 20]. Briefly, $50 \mathrm{ml}$ 267 samples were freeze-dried and resuspended in, $5 \mathrm{ml}, 75 \%$ methanol before enrichment 268 and purification with OASIS HLB cartridges, after the methanol content was diluted to $26915 \%$. Microcystins were eluted with $6 \mathrm{ml}$ methanol, containing $0.1 \%$ Trifluoroacetic 270 acid, dried under nitrogen, resuspended in $80 \%$ methanol and analysed by LC-MS/MS; 271 using a Waters Acquity UPLC and a Quattro Premier XE Mass Spectrometer, run in 272 electrospray positive mode (ESI).

276 CM5 research grade chips were used on a Biacore Q instrument. CM5 chips were 277 coated with MC-LR using the method devised by Vinogradova et al [32]. The flow rate 278 was $20 \mu 1 \mathrm{~min}^{-1}$ for 4 min per cycle, with the 5C4 monoclonal antibody used at a 1 in 2791000 dilution (v/v) using the $0.88 \mathrm{mg} \mathrm{ml}^{-1}$ stock solution. $5 \mathrm{C} 4$ was mixed with sample 280 prior to injections using a blend of $30 \%$ antibody and $70 \%$ sample. The calibration 281 curve consisted of six points; 10, 5, 2.5, 1, 0.5 and $0 \mathrm{ng} \mathrm{ml}^{-1} \mathrm{MC}-\mathrm{LR}$. Calibrants were 282 prepared in matrix ( $M$. aeruginosa CCAP 1450/3 lysate) to normalise for matrix 283 effects. Regeneration of the chip surface was achieved by injecting $75 \mathrm{mM}$ Sodium 284 hydroxide and $10 \%$ Acetonitrile (in deionised water) for $1 \mathrm{~min}$ at $20 \mu \mathrm{min}^{-1}$. 


\section{3. Results and Discussion}

\subsection{Milk Frother Validation}

288 Validation of the frother required testing samples lysed by both the laboratory based 289 paint shaker [27] and portable frother by SPR. This was due to the observation that 290 disintegration of the glass beads occurred upon mixing, which resulted in the 291 appearance of small fragments, which could be mistaken for M. aer cells when viewed 292 microscopically, See Fig 1 for images. To overcome this, identical samples were tested 293 by SPR. For one sample, the paint shaker and $0.5 \mathrm{~mm}$ beads were employed and for 294 the other the frother and $0.1 \mathrm{~mm}$ beads were used. The ratio of $1 \mathrm{~g}$ per $2 \mathrm{ml}$ of sample 295 was maintained, thus $2.5 \mathrm{~g}$ of $0.1 \mathrm{~mm}$ glass beads were added to the $5 \mathrm{ml}$ sample. The 296 same mixing time was used for both, $10 \mathrm{~min}$. The final samples were then tested by

297 SPR to determine the toxin concentrations present. The concentration as determined by 298 the paint shaker method was $9.0 \mathrm{ng} \mathrm{ml}^{-1}$, while that of the frother method was $9.25 \mathrm{ng}$ $299 \mathrm{ml}^{-1}$, resulting in a $103 \%$ recovery of microcystin.. This confirmed that the lysis 300 procedure was as effective as that of the paint shaker.

\subsection{Assay Format}

303 The format of the assay was competitive inhibition, whereby the more microcystins that

304 were present in a sample/calibrant, the less anti-microcystin, 5C4, monoclonal there

305 was available to bind to the surface bound TPC. Thus the more microcystins present in 306 a given sample, the lower the signal would be. This is shown in Fig 2, showing the

307 fluorescence recorded for the four identical microcystin spots, on cartridges with 308 calibrants added. 


\subsection{Assay Validation}

312 The limit of detection (LOD) was determined by taking the mean response for 20 313 negative (toxin free) samples and subtracting $3 \mathrm{x}$ standard deviations (S.D.) as is

314 standard for inhibition assays [33]. The response was then converted to concentration

315 via the calibration curve and derived as $0.78 \mathrm{ng} \mathrm{ml}^{-1}$ (see Table 1). This level was used

316 as a guide to estimate the detection capability $(C C \beta)$, which was $1 \mathrm{ng} \mathrm{ml}^{-1}$, equivalent

317 of the $1 \mu \mathrm{g}^{-1}$ WHO recommended level. Taking into consideration the 10 -fold

318 concentration step in the sample preparation method for intra-cellular measurement,

319 this brings samples containing $0.1 \mathrm{ng} \mathrm{ml}^{-1}$ into the measureable range of the calibration

320 curve. No sample preparation method, other than filtration $(0.45 \mu \mathrm{m})$ was included for

321 free microcystin measurement, as this would only serve to reduce the speed of analysis.

322 As can be seen from Fig 3, there was no overlap between the $20 \times 1 \mathrm{ng} \mathrm{ml}^{-1}$ spiked 323 samples and the 20 negative samples from the LOD calculation (to 1x S.D.).

324 Populations were also shown to be significantly different with a $p$ value $<0.0001 ; 2$ -

325 tailed, unpaired t-test. The assay had a dynamic range $\left(\mathrm{IC}_{10}\right.$ to $\left.\mathrm{IC}_{90}\right)$ of 0.22 to $5.12 \mathrm{ng}$ $326 \mathrm{ml}^{-1}$.

328 Repeatability and reproducibility (intra- and inter-run robustness) were demonstrated

329 by spiking at 3 different toxin levels, with 4 replicates per spiking level, across 2 330 batches of cartridges and repeating this over 3 days. The data was then analysed per

331 day to determine repeatability of the assay and then across the 3 days to determine the 332 reproducibility of the assay. The 3 spiking levels chosen were $\mathrm{CC} \beta$, the midpoint $\left(\mathrm{IC}_{50}\right)$ 333 and the level at which $75 \%$ inhibition of signal was achieved $\left(\mathrm{IC}_{75}\right)$, which were $1,1.27$

334 and $2.78 \mathrm{ng} \mathrm{ml}^{-1}$ respectively. Inter-run analysis showed that spiking level recoveries 335 all lay between 78 and $91 \%$ with \% C.V.s lower than 15\% (see Table 2). For intra-run 
336 analysis, recoveries were between 73 and $96 \%$ with \% C.V.s below $22 \%$ (see Table 2).

337 This demonstrated a high degree of repeatability for what is a semi-quantitative assay, 338 and providing values that could be expected with a fully quantitative, laboratory based 339 assay,

341 Final validation of the assay was performed by testing samples by the SnapEsi method 342 and comparing them to values determined by LC-MS/MS analysis. Table 3 shows the

343 calculated concentrations of the $5 M$ aeruginosa strains tested. The two microcystin 344 pools were combined to give a total microcystin content of each sample. These were 345 then compared to the concentrations derived by LC-MS/MS analysis and as can be seen 346 from the data in Table 4 the difference between the calculated concentrations is 347 between 0.8 to 1.3 -fold, with an average of a 1.04 -fold difference. Differing sample 348 preparation methods in addition to the differing detection methods generally result in 349 much greater variation in data generated. The $\mathrm{R}^{2}$ value, when the calculated 350 concentrations were plotted against each other, Fig 4, was 0.9954 , demonstrating the 351 reliability and accuracy of the method.

\section{4. Conclusions}

354 Due to the true and accurate level of microcystins in a water sample only being 355 ascertained if both free and cell-bound levels are quantified, a method has been 356 developed, and fully validated, to allow the calculation of the total microcystin content 357 of a sample. To allow for the development of a rapid and portable assay, a novel 358 method of cell lysis was also developed and validated, whereby a frother was used to 359 vigorously agitate a sample containing, $0.1 \mathrm{~mm}$ glass beads, mechanically lysing the 
360 cyanobacterial cells, without the need for harsh chemicals, in just $10 \mathrm{~min}$. The planar

361 waveguide assay, using a SnapEsi ${ }^{\circledR}$ LS sensor, is rapid, taking only 15 min and using

362 an anti-microcystin monoclonal antibody (5C4), that detects the more common, and

363 toxic, variants of microcystin; MC-LR, MC-RR, MC-YR, MC-LA, MC-LW and MC-

364 LF. The assay can detect free microcystins to $1 \mathrm{ng} \mathrm{ml}^{-1}$ and intracellular microcystins

365 to $0.1 \mathrm{ng} \mathrm{ml}^{-1}$. The difference being due to a $10 \mathrm{x}$ concentration step that was included

366 in the intracellular sample preparation method; no sample preparation method was

367 required in the measurement of the free microcystin fraction. In addition to this, a 368 single, cheap, cartridge is used per sample that is simply discarded after reading, to give

369 an assay that is not only rapid and portable, but has quantitative capabilities that many

370 semi-quantitative laboratory based methods fail to reach.

\section{Acknowledgements}

372 The authors would like to thank the Department of Employment and Learning (DEL)

373 for funding the project, BEACONS (Biosafety for EnvironmentAL Contaminants using

374 Novel Sensors) (Reference, USI 001) via the US-Ireland Research Programme. The

375 authors also wish to thank Prof Vitor Vasconcelos of the University of Porto (CIIMAR)

376 for providing Microcystis aeruginosa cultures.. Thanks also to Dr Terry Fodey for his

377 invaluable help in preparing the conjugation chemistry protocols.

379 References

380 [1] R.E. Kopp, J.L. Kirschvink, I. a Hilburn, C.Z. Nash, Proceedings of the National

381 Academy of Sciences of the United States of America, 102 (2005) 11131-11136.

382 [2] G.A. Codd, L.F. Morrison, J.S. Metcalf, Toxicology and applied pharmacology, 203

383 (2005) 264-72. 
384 [3] M.E. van Apeldoorn, H.P. van Egmond, G.J. a Speijers, G.J.I. Bakker, Molecular 385 Nutrition \& Food Research, 51 (2007) 7-60.

386 [4] A. Chia, S. Oniye, Z. Ladan, Z. Lado, A. Pila, V. Inekwe, J. Mmerole, African 387 Journal of Biotechnology, 8 (2009) 6282-6289.

388 [5] U. Apte, P. Krishnamurthy, in: S. Monga (Ed.), Molecular Pathology of Liver 389 Diseases, Springer, 2010, 2010, pp. 147-163.

390 [6] W.J. Fischer, S. Altheimer, V. Cattori, P.J. Meier, D.R. Dietrich, B. Hagenbuch, 391 Toxicology and Applied Pharmacology, 203 (2005) 257-263.

392 [7] M.L. Wickstrom, S. a. Khan, W.M. Haschek, J.F. Wyman, J.E. Eriksson, D.J. 393 Schaeffer, V.R. Beasley, Toxicologic Pathology, 23 (1995) 326-337.

394 [8] L. Pearson, T. Mihali, M. Moffitt, R. Kellmann, B. Neilan, Marine drugs, 8 (2010) $395 \quad 1650-80$.

396 [9] S. Pouria, a de Andrade, J. Barbosa, R. Cavalcanti, V. Barreto, C. Ward, W. Preiser, 397 G.K. Poon, G. Neild, G. Codd, The Lancet, 352 (1998) 21-26.

398 [10] Iarc Monographs On The Evaluation Of Carcinogenic Risks To Humans, 94 399 (2010).

400 [11] R. Nishiwaki-Matsushima, T. Ohta, S. Nishiwaki, M. Suganuma, K. Kohyama, T. 401 Ishikawa, W.W. Carmichael, H. Fujiki, Journal of Cancer Research and Clinical 402 Oncology, 118 (1992) 420-424.

403 [12] A. Sieroslawska, Central-European Journal of Immunology, 35 (2010) 105-110.

404 [13] WHO, (2008) 407-408.

405 [14] D. Campbell, L. Lawton, K. Beattie, G. Codd, Environmental Toxicology and 406 Water Quality: An International Journal, 9 (1994) 71-77.

407 [15] I. Chorus, J. Bartram, (1999).

408 [16] H.G. Gorchev, G. Ozolins, WHO chronicle, 38 (1984) 104-8.

409 [17] K. Tsuji, T. Watanuki, F. Kondo, M. Watanabe, H. Nakazawa, M. Suzuki, H.

410 Uchida, K. Harada, Toxicon, 35 (1997) 1033-1041.

411 [18] V.K. Sharma, T.M. Triantis, M.G. Antoniou, X. He, M. Pelaez, C. Han, W. Song, 412 K.E.O. Shea, A.A. De, T. Kaloudis, A. Hiskia, D.D. Dionysiou, Separation and 413 Purification Technology, 91 (2012) 3-17.

414 [19] L. Spoof, K. Karlsson, J. Meriluoto, Journal of chromatography. A, 909 (2001) $415225-36$. 
416 [20] K.M. Mooney, J.T.G. Hamilton, S.D. Floyd, R.H. Foy, C.T. Elliott, Environmental 417 Toxicology, 26 (2011) 556-570.

418 [21] L. Lawton, C. Edwards, K. Beattie, S. Pleasanc, G. Dear, G. Codd, Natural Toxins, 4193 (1995) 50-57.

420 [22] L.N. Sangolkar, S.S. Maske, T. Chakrabarti, Water research, 40 (2006) 3485-96.

421 [23] Y.M. Kim, S.W. Oh, S.Y. Jeong, D.J. Pyo, E.Y. Choi, Environmental Science \& 422 Technology, 37 (2003) 1899-1904.

423 [24] F. Long, M. He, a N. Zhu, H.C. Shi, Biosensors \& Bioelectronics, 24 (2009) 424 2346-2351.

425 [25] S. Herranz, M.D. Marazuela, Biosensors and Bioelectronics, 33 (2012) 50-55.

426 [26] J.P. Meneely, K. Campbell, C. Greef, M.J. Lochhead, C.T. Elliott, Biosensors and 427 Bioelectronics, (2012).

428 [27] R. Devlin, K. Campbell, K. Kawatsu, C.T. Elliott, Harmful Algae, 10 (2011) 542429548.

430 [28] M.J. Lochhead, K. Todorof, M. Delaney, J.T. Ives, C. Greef, K. Moll, K. Rowley, 431 K. Vogel, C. Myatt, X. Zhang, C. Logan, C. Benson, S. Reed, R.T. Schooley, Journal 432 of Clinical Microbiology, 49 (2011) 3584-3590.

433 [29] I. Kim, G. Nguyen, S. Kim, J. Lee, H. Yu, Environmental Engineering Research, 43414 (2009) 250-254.

435 [30] L. Lawton, C. Edwards, G. Codd, The Analyst, 119 (1994) 1525-30.

436 [31] T. a M. Msagati, B. a Siame, D.D. Shushu, Aquatic toxicology (Amsterdam, 437 Netherlands), 78 (2006) 382-97.

438 [32] T. Vinogradova, M. Danaher, A. Baxter, M. Moloney, D. Victory, S. a. Haughey, 439 Talanta, (2011) 1-6.

440 [33] J.P. Meneely, M. Sulyok, S. Baumgartner, R. Krska, C.T. Elliott, Talanta, 81 441 (2010) 630-6.

442

443 List of Figures:

444 Fig 1. Image a (x 200 magnification) shows $0.1 \mathrm{~mm}$ glass beads after $10 \mathrm{~min}$ mixing

445 with the milk frother. The majority of beads disintegrate forming small fragments that 446 may be mistaken for cyanobacterial cells. Image b (x 200 magnification) shows CCAP 
447 1450/6 M. aeruginosa cells; which would be difficult to distinguish amongst the bead 448 fragments in image a.

449 Fig 2. Images of microcystin spots as treated with calibrants: a, $10 \mathrm{ng} \mathrm{ml}^{-1}$; b,

$450 \quad 2.5 \mathrm{ng} \mathrm{ml}^{-1} ; \mathrm{c}, 1 \mathrm{ng} \mathrm{ml}^{-1}$; and d, $0 \mathrm{ng} \mathrm{ml}^{-1}$.

451 Fig 3. Determination of CC $\beta$ as $1 \mathrm{ng} \mathrm{ml}^{-1}$, as shown by the $0 \mathrm{ng} \mathrm{ml}^{-1}$ and $1 \mathrm{ng} \mathrm{ml}^{-1}$

452 populations not overlapping (to 1 S.D.)

453 Fig 4. Comparison of mBio and LC-MS/MS results, showing a good correlation,

454 whereby $\mathrm{R}^{2}=0.9954$.

455

456 List of Tables:

457 Table 1. Determination of LOD as $0.78 \mathrm{ng} \mathrm{ml}^{-1}$

458 Table 2. Measured concentrations of spiked samples, along with S.D., \% C.V.s and

459 mean recoveries, for repeatability and reproducibility analysis of assay.

460 Table 3. Microcystin content of M. aeruginosa cultures as calculated by mBio

461 SnapEsi.

462 Table 4. Comparison of mBio and mass spec concentrations for toxin producing $M$.

463 aeruginosa samples. 


\begin{tabular}{cccccc}
\hline \multicolumn{9}{c}{ Response (Normalised Signal) } & & \multicolumn{1}{c}{$\begin{array}{c}\text { Calc Conc } \\
\left(\mathrm{ng} \mathrm{m}^{-1}\right)\end{array}$} \\
\hline Mean & S.D. & \% C.V. & 3x[S.D.] & LOD & \\
\hline 1060.9 & 133.8 & 12.6 & 401.4 & 659.5 & 0.78 \\
\hline
\end{tabular}


467

\begin{tabular}{ccccc}
\cline { 2 - 5 } & $\begin{array}{c}\text { Spiking Level } \\
\left(\mathrm{ng} \mathrm{m}^{-1}\right)\end{array}$ & $\begin{array}{c}\text { Measured } \\
\text { Concentration } \\
\left(\mathrm{ng} \mathrm{ml}^{-1}\right) \pm \text { S.D. }\end{array}$ & C.V. (\%) & $\begin{array}{c}\text { Mean } \\
\text { Recovery (\%) }\end{array}$ \\
\cline { 2 - 5 } Day 1 & 1 & $0.95 \pm 0.13$ & 14.0 & 95.1 \\
\cline { 2 - 5 } & 1.27 & $0.99 \pm 0.28$ & 21.9 & 78.2 \\
\hline \multirow{3}{*}{ Day 2 } & 2.78 & $2.03 \pm 0.39$ & 19.3 & 73.1 \\
\cline { 2 - 5 } & 1 & $0.86 \pm 0.13$ & 15.5 & 85.9 \\
\hline \multirow{2}{*}{ Day 3 } & 1.27 & $1.06 \pm 0.28$ & 26.3 & 83.3 \\
\cline { 2 - 5 } & 2.78 & $2.02 \pm 0.36$ & 17.6 & 72.6 \\
\hline Overall & 1.27 & $0.91 \pm 0.10$ & 10.5 & 90.9 \\
\cline { 2 - 5 } (Days 1 to 3) & $1.29 \pm 0.11$ & 8.4 & 101.3 \\
\cline { 2 - 5 } & 1.27 & $2.49 \pm 0.44$ & 17.8 & 89.4 \\
\hline
\end{tabular}

468

469 


\begin{tabular}{|c|c|c|c|}
\hline Culture & $\begin{array}{l}\text { Cell bound } \\
\text { Concentration } \\
\left(\mathrm{ng} \mathrm{ml}^{-1}\right)\end{array}$ & $\begin{array}{l}\text { Free Concentration } \\
\qquad\left(\mathrm{ng} \mathrm{ml}^{-1}\right)\end{array}$ & $\begin{array}{c}\text { Total Concentration } \\
\qquad\left(\mathrm{ng} \mathrm{ml}^{-1}\right)\end{array}$ \\
\hline $1450 / 06$ & 7.9 & 21.2 & 29.2 \\
\hline 91093 & 63.6 & 16.5 & 80.1 \\
\hline 91094 & 38.7 & 21.6 & 60.3 \\
\hline 91095 & 128.2 & 461.5 & 589.7 \\
\hline 91096 & 72.5 & 18.2 & 90.7 \\
\hline
\end{tabular}

470

471

472 
472

\begin{tabular}{cccc}
\hline Culture & \multicolumn{2}{c}{ Calculated Concentration $(\mathbf{n g} / \mathbf{m l})$} & $\begin{array}{c}\text { Difference } \\
(\mathbf{x}-f \text { fold })\end{array}$ \\
\hline $\mathbf{1 4 5 0 / 0 6}$ & 29.2 & Mass Spec & 0.8 \\
\hline $\mathbf{9 1 0 9 3}$ & 80.1 & 23.7 & 1.3 \\
\hline $\mathbf{9 1 0 9 4}$ & 60.3 & 108.1 & 1.1 \\
\hline $\mathbf{9 1 0 9 5}$ & 589.7 & 64.5 & 0.9 \\
\hline $\mathbf{9 1 0 9 6}$ & 90.7 & 536.2 & 1.1 \\
\hline
\end{tabular}

473

474 


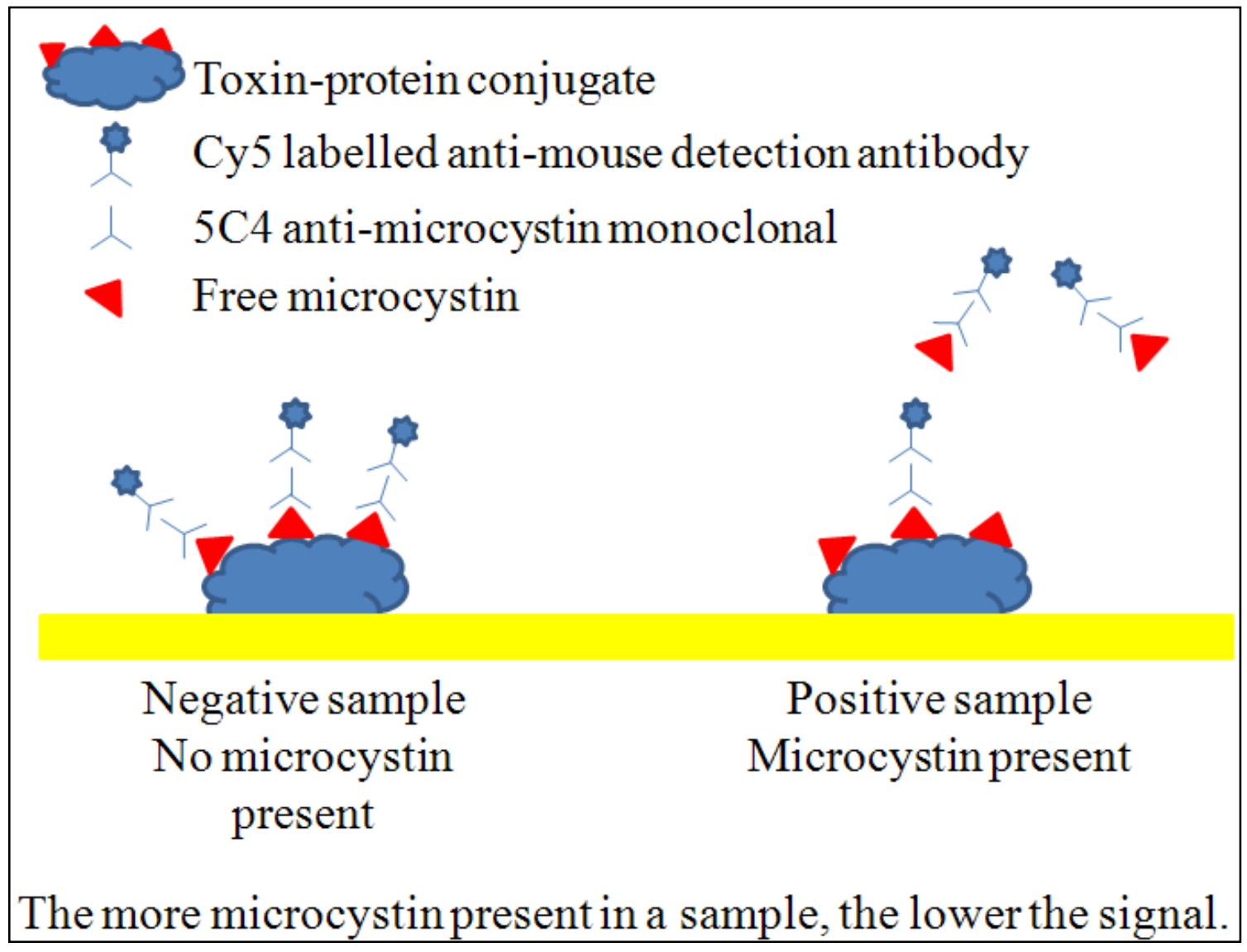

6. Read Signal

5. Application of sample

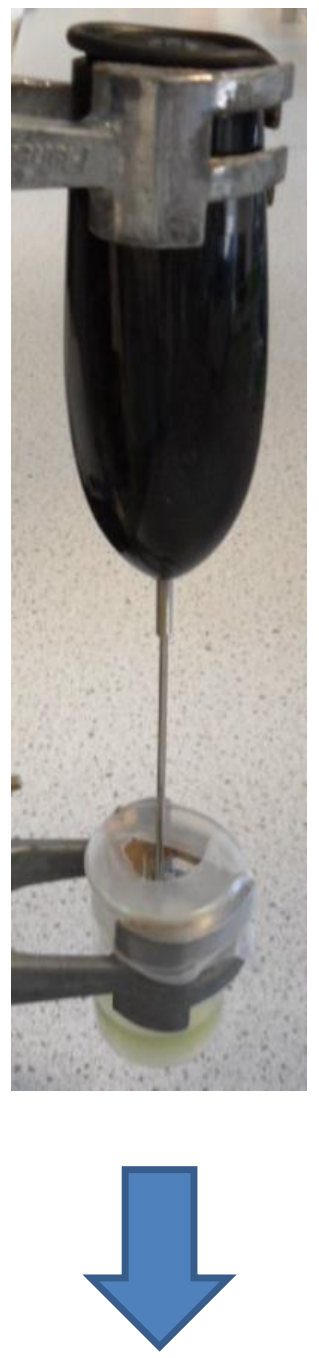

4. Sample filtration 

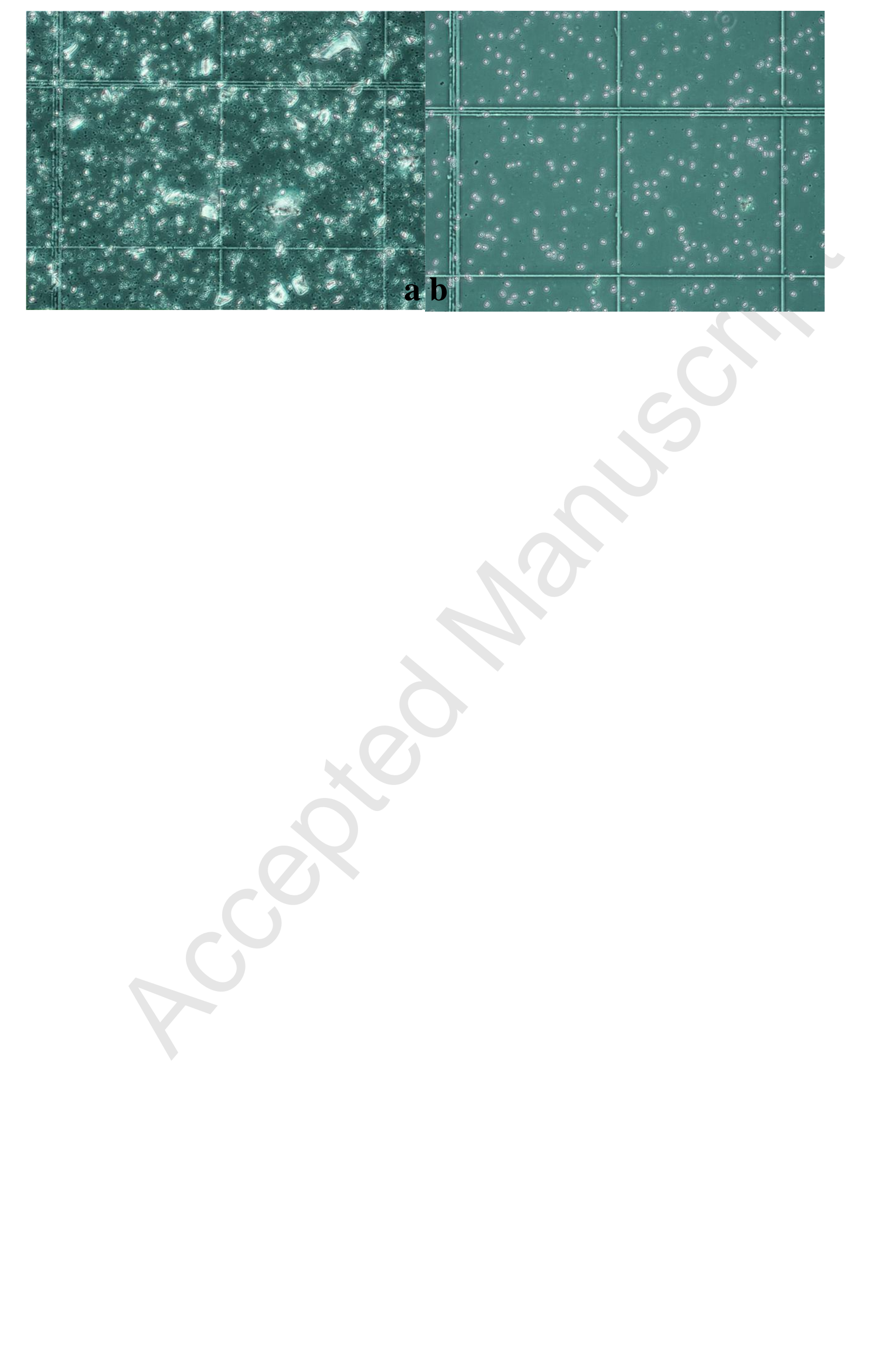


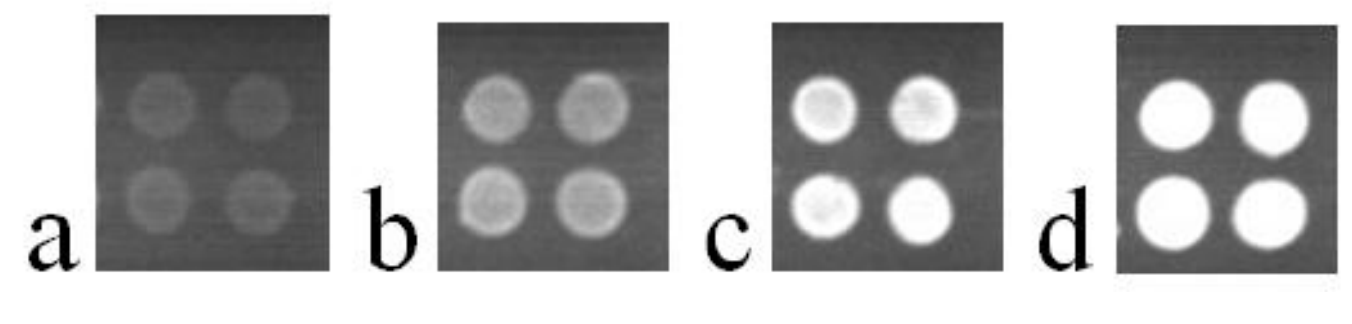

d 


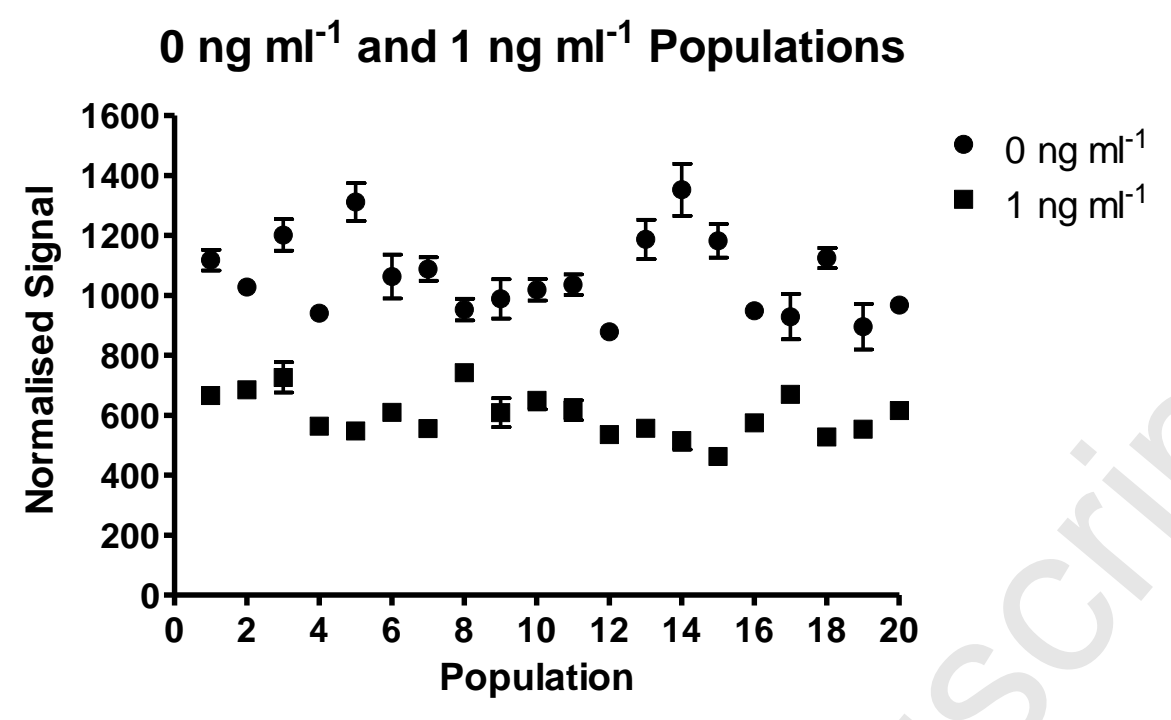




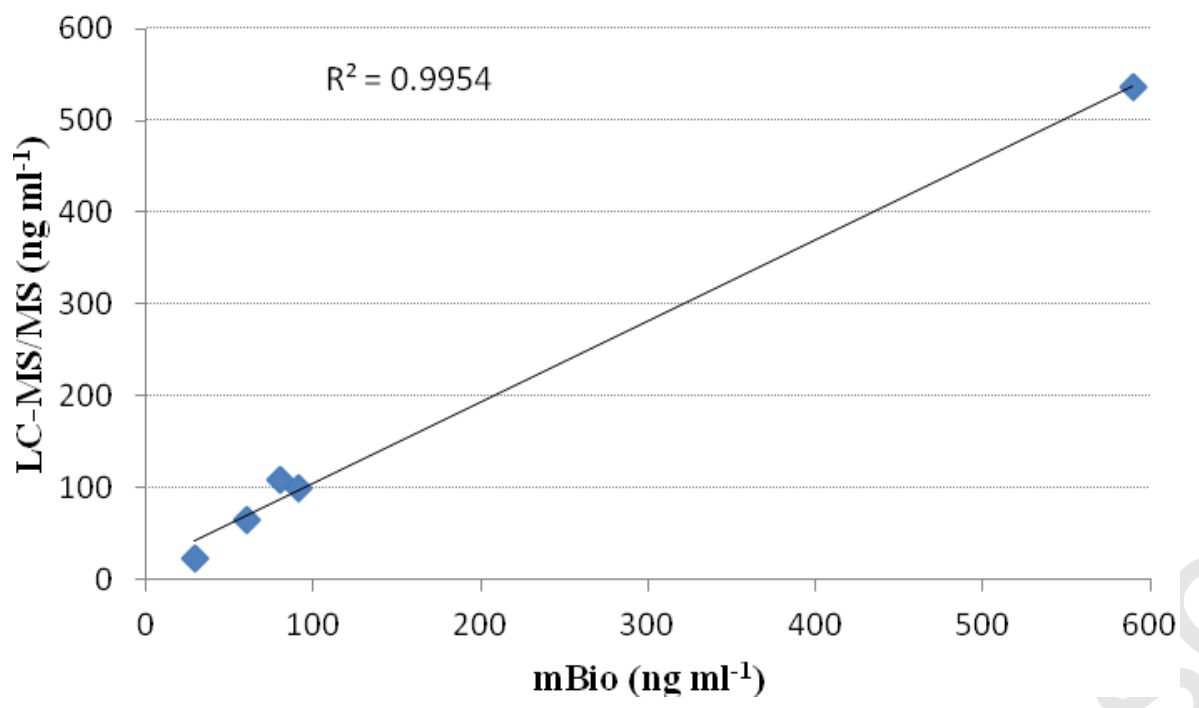

